\title{
YAYIKALTI İÇECEĞİNİN FİZİKOKİMYASAL VE DUYUSAL ÖZELLİKLERİ İLE UÇUCU BİLEŞENLERİNİN BELİRLENMESİ
}

\author{
Çisem Öğe ${ }^{1}$, Yonca Karagül Yüceer ${ }^{2 *}$ \\ ${ }^{1}$ Çanakkale Onsekiz Mart Üniversitesi, Ezine Meslek Yüksekokulu, Çanakkale, Türkiye \\ ${ }^{2}$ Çanakkale Onsekiz Mart Üniversitesi, Mühendislik Fakültesi, Gıda Mühendisliği Bölümü, Çanakkale, Türkiye
}

Geliş / Received: 05.05.2021; Kabul / Accepted: 13.08.2021; Online bask1 / Published online: 20.09.2021

Öğe, C.., Karagül Yüceer, Y. (2021). Yayıkaltı içeceğinin fizikokimyasal ve duyusal özellikleri ile uçucu bileşenlerinin belirlenmesi. GIDA (2021) 46 (5) 1243-1255 doi: 10.15237/gida.GD21082

Öğe, C.., Karagül Yüceer, Y. (2021). Determination of physicochemical and sensory properties and volatile compounds of buttermilk. drink. GIDA (2021) 46 (5) 1243-1255 doi: 10.15237/gida.GD21082

\section{ÖZ}

Bu çalışmada yayıkalı suyunun farklı mikroorganizmalarla fermantasyonu ile üretilen içeceklerin karakteristik bazı özelliklerinin belirlenmesi amaçlanmıştır. Toz halindeki yayıkalının \%10'luk çözeltisi ile belirli oranlarda $(\% 0,25,50,75,100)$ çiğ süt karışımına 1sıl işlem uygulandıktan sonra örneklere L. acidophilus (LA) kültürü ve $L$ acidophilus, Bifidobacteria ile $S$. thermophilus karışı kültürü (ABT) ilave edilerek $37^{\circ} \mathrm{C}$ 'de, yaklaş1k $4.8 \mathrm{pH}$ 'ya kadar inkübe edilmiştir. Ürünlerin fizikokimyasal ve duyusal özellikleri ve uçucu bileşenleri depolama süresince belirlenmiştir. İçeceklerde yayıkaltı suyu oranı azaldıkça yağ, kurumadde ve protein oranları artmıştr. Örneklerde uçucu bileşenler gaz kromatografisi kütle spektrometrisi kullanılarak belirlenmiştir. Tüm örneklerde belirlenen uçucu bileşikler aseton, 2,3-butandion, asetoin, toluen, 2-heptanon, limonen, ökaliptol, asetik asit ve butanoik asit olmuştur. Yayıkalt içeceklerinde pişmiş, kremamsı, süthane/sütümsü, fermente, karton, yosun, sabunsu, depo, tatli, tuzlu, buruk ve acı terimleri duyusal değerlendirmeler sonucunda belirlenmiştir.

Anahtar kelimeler: Yayıkaltı, fizikokimyasal özellik, uçucu bileşen, duyusal

\section{DETERMINATION OF PHYSICOCHEMICAL AND SENSORY PROPERTIES AND VOLATILE COMPOUNDS OF BUTTERMILK DRINK}

\begin{abstract}
In this study, determination of characteristics some properties of beverages produced by fermentation of buttermilk by different microorganisms was aimed. After heat treatment was carried out by adding different amounts of raw milk $(0,25,50,75,100 \%)$ to $10 \%$ of buttermilk solution, L. acidophilus (LA) culture and L. acidophilus, Bifidobacteria and $S$. thermophilus mixed culture (ABT) were added to samples and incubated at $37^{\circ} \mathrm{C}$ to a $\mathrm{pH}$ of about 4.8 . Physicochemical and sensory properties and volatile compounds of the products were determined during storage. As the amount of milk byproducts decreased, the fat, dry matter and protein ratios increased in buttermilk beverages. Volatile compounds in the samples were determined by using gas chromatography mass spectrometry. The volatile compounds determined in all samples were acetone, 2,3-butanedione, acetoin, toluene, 2heptanone, limonene, eucalyptol, acetic acid and butanoic acid. The terms cooked, creamy,
\end{abstract}

\footnotetext{
"Yazışmalardan sorumlu yazar/ Corresponding Author

(1): yoncayuceer@comu.edu.tr O: (+90) 2862180018 / 20051

国: (+90) 2862180541
}

Çisem Öğe; ORCID no: 0000-0002-3769-5526

Yonca Yüceer; ORCID no: 0000-0002-9028-2923 
dairy/milky, fermented, cardboard, algae, soapy, warehouse, sweet, salty, astringent, and bitter in probiotic beverages were determined as a result of sensory evaluation.

Keywords: Buttermilk, physicochemical property, volatile compounds, sensory

\section{GİRIŞ}

Günümüzde ulaşılabilir gıdanın niceliğinden çok niteliğinin önem kazanmasının yanı sıra tüketicinin çevreye karșı koruyuculuğunun da artması ile önemli bileșenlere sahip gida yan ürünlerine ilgi artmıştır. Kolay ulaşılabilir olması nedeniyle süt, fonksiyonel özellikleri ve fermantasyona uygun hammadde olarak birçok çeşitte ürün üretimine olanak sağlamaktadır. Gıda endüstrisinde önemli bir paya sahip olan süt ve ürünlerinin var olan yan ürün ve atık kapasitesi de buna bağlı olarak artmaktadır. Her ne kadar yan ürün ve atık olarak akla ilk gelen çevre sorunları olsa da gida sektörü açısından yaklaşım besleyici özellik bakımından zengin olan çıktıların değerlendirilmesidir.

Ulusal Süt Konseyi'nin 2019 y1lı Süt Raporunda, süt ürünlerinin üretim ve uluslararas1 ticaretinde en büyük paya sahip ürünler arasında tereyağı da yer almaktadır. Ülkemizde tereyağı üretimi aralık ayı baz alınarak TÜİK tarafindan 2019 yılına göre 2020 y1lında \%16.3 artış göstermiştir (TUiK, 2020).

Yayıkaltı, tereyağ1 üretimi sırasında açığa çıkan besleyici ve fonksiyonel bileşenler içeren önemli bir yan üründür (Morin vd., 2007; Yıldırım ve Güzeller, 2013). Her $100 \mathrm{~kg}$ tereyağ1 üretiminde yaklaşık $166 \mathrm{~kg}$ yayıkaltı suyu açığa çıkmaktadır. Bileşim yönünden yağsız süt ile benzerlik gösteren yayıkaltı suyu ortalama \% 5.1 laktoz, \% 3.5 protein, $\% 0.8$ kül ve $\% 0.1$ yağ içermektedir (Küçük, 2013; Madenci vd., 2013).

Peyniraltı suyu gibi yayıkaltı suyu da birçok gıda üretiminde yap1 iyileștirme, kıvam verme, jel oluşturma gibi olumlu katkılarından dolayı yaygın olarak kullanılmaktadır. Bu olumlu özelliklerinin yanında biyoaktif bileşikleri nedeniyle yayıkaltı suyu besleyici yönden de önem kazanmaktadır. Yayıkaltı suyunun biyoaktif özellikleri protein ve süt fosfolipitlerinden ileri gelmektedir. Tereyağ üretiminde kremaya uygulanan mekanik çalkalama ile parçalanan yağ globülü zarı ile protein, laktoz, mineraller ve bazı yağlar yayıkaltı suyuna geçmektedir. İnce yapıdaki süt yağ globülü zar1 kurumaddede \% 4.43 fosfolipid, \% 13.4 kazein, \% 20.1 serum proteinleri ve \% 21.6 zar proteinleri içermektedir (Morin vd., 2007; Cumhur, 2008). Ayrica son zamanlarda yapilan araştırmalar ile tereyağ1 üretiminde parçalanan süt yağ globül zarından geldiği bilinen ve küçük miktarlarda olmasına karşın beslenme açısından önemli bulunan 130 farklı protein izole edilmiştir (Liutkevičius vd., 2016; Affolter vd., 2010). Ancak hem beslenme hem de yapiya olumlu etkilerinin yanında yayıkaltı suyu ve peyniraltı suyu gibi süt yan ürünlerinin tatlarının pek kabul edilebilir olmaması nedeniyle bu yan ürünlerin doğrudan kullanımı sınırlı kalmaktadır (Arora vd., 2015). Söz konusu süt yan ürünlerinin hem muhafaza ve depolanması hem de farklı gidalarda katkı olarak kullanılabilirlik durumunu arttırması nedeniyle toz formlarının kullanılmasının daha uygun olduğu bilinmektedir (Ylldırım ve Güzeller, 2013; Corredig vd., 2003; Bachmann, 2001).

Yayıkaltı suyu gıda endüstrisinde katkı olarak hâlihazırda kullanılan bir yan üründür. $\mathrm{Bu}$ çalışmanın amacı protein içeriği yüksek ve biyoaktif bileşenlere sahip yayıkaltı suyunun farklı mikroorganizmalarla fermantasyonu sonucu elde edilen içeceklerin bazı karakteristik özelliklerinin belirlenmesidir. Ayrica yayıkaltı suyunun fonksiyonel ürün olarak değerlendirilmesi konusunda süt endüstrisine katk1 sağlanması hedeflenmiştir.

\section{MATERYAL VE YÖNTEM}

$\mathrm{Bu}$ çalışmada hammadde olarak yayıkaltı suyu tozu (Enka Süt, Konya), çiğ inek sütü, kültür olarak ise $L$. acidophilus, Bifidobacteria ve $S$. thermophilus karış1k kültürü (ABT) ve L. acidophilus (LA) kültürü (Chr Hansen, İstanbul) kullanılmıştır.

\section{Yayıkaltı İçeceği Üretimi}

Yayıkaltı içeceği üretimi için kullanılan yayıkaltı suyu tozunun kütlece \%10'luk sulu çözeltisi (YAS) hazırlanmıştır. Hazırlanan YAS ile çiğ inek sütü 5 farklı oranda karıştırılarak (\%100, \% 75, \% 
$50, \% 25$ ve $\% 0$ ) ve 2 farklı kültür ile fermente edilerek toplamda 10 farklı ürün elde edilmiştir.
Elde edilen ürünlerin isimlendirilmesi ve bileşimi Çizelge 1'de yer almaktadır.

Çizelge 1. Yayıkaltı içeceğinin ismi ve içeriği

Table 1. Name of buttermilk beverage and its content

\begin{tabular}{|c|c|c|c|}
\hline $\begin{array}{l}\text { Ürün adi/ Product } \\
\text { name }\end{array}$ & Ürün içeriği/ content of the product & $\begin{array}{l}\text { Ürün adi/ } \\
\text { Product name }\end{array}$ & Ürün içeriği/ content of the product \\
\hline Y100-ABT & $\% 100$ YAS+ABT (kontrol/control) & Y100-LA & $\% 100$ YAS+LA (kontrol/control) \\
\hline Y75-ABT & $\% 75$ YAS+\% 25 süt $/$ milk+ABT & Y75-LA & $\% 75$ YAS+\% $\% 25$ süt $/$ milk+LA \\
\hline Y50-ABT & $\% 50$ YAS+\% 50 süt $/$ milk+ABT & Y50-LA & $\% 50$ YAS+\% 50 süt $/$ milk+LA \\
\hline Y25-ABT & $\% 25$ YAS+\% 75 süt $/$ milk+ABT & Y25-LA & $\% 25$ YAS+\% 75 süt $/$ milk+LA \\
\hline Y0-ABT & $\begin{array}{l}\% 100 \text { süt/milk+ABT } \\
\text { (kontrol/control) }\end{array}$ & Y0-LA & \% 100 süt/milk+LA (kontrol/control) \\
\hline
\end{tabular}

YAS: Yayıkaltı suyu/buttermilk.

Yayıkaltı içeceği üretimi için hazırlanan YAS ve çiğ inek sütü belirtilen oranlarda karıştırıldıktan sonra su banyosunda yaklaşık $65^{\circ} \mathrm{C}$ 'de 30 dakika boyunca pastörize edilmiştir. Pastörizasyon sonrası hızlıca kültür inokülasyon sıcaklığına (37 ${ }^{\circ} \mathrm{C}$ ) soğutulmuş ve ürünlere kültür ilavesi yapılmıştır. Ürünler $37^{\circ} \mathrm{C}$ 'de $\mathrm{pH}$ değeri $4.8^{\prime} \mathrm{e}$ ulaşıncaya kadar inkübasyona bırakılmıştır. $4.8 \mathrm{pH}$ değerine ulaşan ürünler $+4{ }^{\circ} \mathrm{C}$ ye hizlıca soğutulmuş ve $200 \mathrm{~mL}$ 'lik kaplara aktarılmıştır. Elde edilen yayıkaltı içecekleri $+4{ }^{\circ} \mathrm{C}$ 'de 15 gün süreyle depolanmıştır. Depolamanın 1. ve 15. günlerinde ürünlerde $\mathrm{pH}$ ölçümü, toplam asitlik, kurumadde, protein, yağ, viskozite, uçucu bileşen ve tanımlayıcı duyusal analizler gerçekleştirilmiştir.

\section{Çiğ Süt ve YAS Analizleri}

Çiğ süt ve YAS için başlangıçta $\mathrm{pH}$ ölçümü (Sartorius Basic Meter PB-11, Göttingen, Almanya), \% laktik asit cinsinden toplam asitlik, $\%$ protein ve $\%$ kurumadde analizleri Bradley vd. (1992) tarafindan önerilen yönteme göre \% yă analizi ise Gerber van Gulik metodu (NEN, 1969) ile gerçekleştirilmiştir.

\section{Yayıkaltı İçeceği Analizleri}

Yayıkaltı içeceklerine, YAS ve çiğ süte uygulanan analizlerin yanı sıra viskozite, uçucu bileşen ve tanımlayıcı duyusal analizler uygulanmıştır. Viskozite ölçümleri Enhanced UL adaptörü kullanilan viskozimetre (Model DV II+Pro; Brookfield Engineering Laboratories, Inc., MA, ABD) ile gerçekleștirilmiştir. Uçucu bileşenlerin izolasyonu ve tanımlanması amaciyla sırasıly katı faz mikroekstraksiyon (SPME) ve Gaz Kromatografisi Kütle Spektrometresi (GC-MS) (GC 6890, MS 6890N Agilent Technologies, Wilmington DE, ABD) kullanılmıştır. İzole edilen bileşenlerin tanımlanması amaciyla spektral kütüphaneler kullanılmışır (NIST, 2008 ve Wiley, 2005). Bazı uçucu bileşenler iyon taraması yöntemi kullanılarak belirlenmiştir. Kütüphane taramasinda aseton 58, asetik asit 60 ve 2,3butandion 86 iyonu kullanılarak tespit edilmiştir. Uçucu bileşenlerin miktarı Avşar vd. (2004) tarafından önerilen yönteme göre belirlenmiştir. Örneklerde bulunan asidik bileşiklerin miktarı toplam alana göre \% ortalama oran şeklinde hesaplanmıştır. Yayıkaltı ürünlerinin tanımlayıcı duyusal analizi Spectrum ${ }^{\mathrm{TM}}$ metodu kullanilarak; yaşlann 18-50 arasında değisşen 6 eğitimli panelist (1 erkek 5 kadın) tarafindan gerçekleştirilmiştir (Meilgaard vd., 1999).

Ürünlerin üretimi ve analizleri iki tekrarlı olarak gerçekleştirilmiştir. Yayıkaltı tozunun ve sütün hammadde olarak alındığı çalışmada dikkate alınan örnek oranlarının $(100,75,50,25,0)$, depolama sürelerinin (1 ve 15) ve kültür çeşidinin (ABT ve LA) belirlenen özelliklere (protein, yağ, kurumadde, $\mathrm{pH}$, titrasyon asitliği, viskozite, duyusal özellikler) etkisinin araştırılmasında faktöriyel düzeyde varyans analizi tekniği kullanılmıştır. Ayrıca örnekler arasında farklilıkların belirlenerek değerlendirilmesinde Tukey çoklu karşılaştırma testinden yararlanılmıştır. Söz konusu istatistik analizlerin 
uygulanmasinda Minitab (version 17) ve SPSS (version 20) istatistik paket programları kullanılmıştır.

\section{SONUÇ VE TARTIŞMA}

Çalışmada elde edilen ürünlerin hammaddesi olan YAS ve çiğ inek sütüne ait genel bileşen değerleri ortalamaları alınarak hesaplanmıştır. Çiğ inek sütü için $\mathrm{pH}$ 6.36, toplam asitlik (\%) laktik asit cinsinden $0.18, \%$ kurumadde $11.59, \%$ yağ 3.27 ve $\%$ protein 3.25 ; YAS için $\mathrm{pH} 6.72$, toplam asitlik (\%) laktik asit cinsinden $0.15, \%$ kurumadde
9.51, \% yağ 0.90 ve $\%$ protein 2.67 olarak tespit edilmiştir.

Genel bileşen analiz sonuçlarına bakıldığında ürünlerin kurumadde $(\%)$ ve yağ (\%) değeri üzerine istatistiksel olarak sadece örnek oranlarının etkisi önemli bulunmuştur ( $\mathrm{P} \leq 0.05$; Çizelge 2). Örnekler arasındaki orana bağlı farkll1lklar genel bileşime uygun olarak özellikle kurumadde $(\%)$ ve yă $(\%)$ değerleri açısından sadece YAS içeren kontrol örneklerinden süt örneklerine doğru artış göstermiştir.

Çizelge 2. Yayıkaltı içeceklerin genel bileşimi (Ortalama \pm S.H.)

Table 2. General composition of buttermilk beverages (Mean士S.E.)

\begin{tabular}{lccccc}
\hline \multirow{2}{*}{$\begin{array}{l}\text { Özellik/Properties } \\
(\%)\end{array}$} & 100 & 75 & 50 & 25 & 0 \\
\cline { 2 - 6 } & $0.75 \pm 0.07 \mathrm{c}$ & $1.17 \pm 0.06$ c & $2.08 \pm 0.13 \mathrm{~b}$ & $2.65 \pm 0.23 \mathrm{~b}$ & $4.27 \pm 0.15$ a \\
\hline Yağ/ Fat & $8.18 \pm 0.19 \mathrm{~cd}$ & $8.67 \pm 0.23$ c & $9.48 \pm 0.21 \mathrm{bc}$ & $10.09 \pm 0.23 \mathrm{~b}$ & $11.60 \pm 0.32$ a \\
Kurumadde/Dry matter & $2.55 \pm 0.03 \mathrm{c}$ & $2.59 \pm 0.06 \mathrm{c}$ & $2.80 \pm 0.03 \mathrm{~b}$ & $2.91 \pm 0.04 \mathrm{~b}$ & $3.20 \pm 0.03$ a \\
\hline
\end{tabular}

YAS: Yayıkalt1 suyu/buttermilk S.H.: Standart hata/ S.E.: Standard Error. n:10

a-dAynı satırda farklı küçük harf ile gösterilen değerler arasındaki farklar önemlidir $(\mathrm{P} \leq 0.05)$.

Yayıkaltı içeceklerinin \% protein değeri üzerine hem YAS oranının hem de kültür çeşidinin etkisi önemli bulunmuştur $(\mathrm{P} \leq 0.05)$. Buna göre $\mathrm{ABT}$ kültürü ile fermente edilmiş YAS içeren örneklerin, LA kültürü ile fermente edilmiş örneklere göre daha düşük protein oranına sahip olduğu görülmüştür. ABT kültürü ile fermente edilen örneklerin ortalama \pm standart hata olarak protein değeri $2.76 \pm 0.05$ iken LA kültürü ile fermente edilmiş probiyotik ürünlerin ortalama protein değeri $2.86 \pm 0.06$ olarak bulunmuştur. Örnek oranlarına bakıldığında ise sadece yayıkaltı suyu tozu içeren örneklerden sadece süt içeren örneğe doğru protein oranı düzenli şekilde artış göstermiştir (Çizelge 2).

Yayıkaltı ürünlerinin $\mathrm{pH}$ değerleri üzerine depolama günü ve örnek oranlarının etkisi önemli bulunmuştur (Çizelge 3; $\mathrm{P} \leq 0.05$ ). Ürünlerin $\mathrm{pH}$ değerlerinde $\% 100$ oranından $\% 0$ YAS oranına doğru bir düşüş olduğu saptanmıştır. Ayrıca üretimde inkübasyon aşamasının en uzun sürdüğü ürün çeşidi de \% 100 YAS içeren örnekler olmuştur. Bu durumun, üretimde inoküle edilen starter kültürlerin ihtiyaç duyduğu laktozun, tereyağ1 üretiminde kullanılan starter kültürler tarafindan kullanılmış olması veya yayıkaltı suyunun toz forma dönüştürülmesi sırasındaki laktoz kaybına bağlı olduğu düşünülmektedir. Ek olarak, 15 günlük depolama süresince ilk gün daha yüksek olan (ortalama $\mathrm{pH}$ 4.67) $\mathrm{pH}$ değerleri son günde (ortalama pH 4.54) düşüş göstermiştir.

İçeceklerin laktik asit cinsinden toplam asitlik değerlerine depolama gününün etkisi önemli bulunmuştur ( $(P \leq 0.05)$; Çizelge 4$)$. Depolama boyunca takip edilen laktik asit (\%) cinsinden toplam asitlik ilk güne göre tüm örneklerde daha düşükken son depolama gününde artmıştır. Özellikle üretimde inkübasyon sonrası kültürün ortama uyum sağlaması ile gelişme göstererek ürünlerin toplam asitliğini arttırdığ1 görülmüştür. Laktaz etkinliği açısından $L$. acidopbilus' un Lactobacillus türleri içerisinde en yüksek değere sahip olduğu bilinmektedir (Akal ve Yetişemeyen, 2020). Çalışmada ABT karışık kültürü ile fermente 
edilmiş ürünlerin asitlikleri, ilk depolama gününde LA kültürü ile fermente edilenlere göre daha yüksek iken son depolama gününde $\% 25$ ve $\% 0$ YAS içeren ürünler dissında tam tersi bir durum söz konusu olmuştur. Bu durum LA kültürünün farklı gelişim fazlarında olabileceği ve ortama uyum sağladıktan sonra hızlı bir gelişim eğrisi göstererek laktozu parçalaması ve laktik asit cinsinden toplam asitliği yükseltmesi şeklinde açıklanabileceği gibi L. acidophilus' un glikozu fermente edebilmesi ancak galaktozu tam olarak metabolize edememesine de bağlanabilir (Hayatoğlu, 2021).

Çizelge 3. Yayıkaltı içeceklerinin depolama süresince $\mathrm{pH}$ değerleri (Ortalama \pm S.H.) Table 3. $p H$ values of buttermilk beverages during storage (Mean士S.E.)

\begin{tabular}{|c|c|c|c|c|c|}
\hline \multirow{3}{*}{$\begin{array}{l}\text { YAS Oran1/ } \\
\text { Rate of } Y A S(\%)\end{array}$} & \multicolumn{2}{|c|}{ 1. Gün/Day 1} & \multicolumn{2}{|c|}{ 15. Gün/Day 15} & \multirow{3}{*}{ Ortalama/Mean } \\
\hline & \multicolumn{4}{|c|}{ Kültür Çeşidi/Type of Culture } & \\
\hline & $\mathrm{ABT}$ & LA & ABT & LA & \\
\hline 100 & $4.79 \pm 0.03$ & $4.98 \pm 0.19$ & $4.67 \pm 0.14$ & $4.77 \pm 0.26$ & $4.80 \pm 0.08$ a \\
\hline 75 & $4.69 \pm 0.04$ & $4.81 \pm 0.08$ & $4.53 \pm 0.08$ & $4.69 \pm 0.18$ & $4.68 \pm 0.05 \mathrm{ab}$ \\
\hline 50 & $4.56 \pm 0.00$ & $4.61 \pm 0.05$ & $4.40 \pm 0.08$ & $4.49 \pm 0.09$ & $4.51 \pm 0.03 \mathrm{~b}$ \\
\hline 25 & $4.61 \pm 0.02$ & $4.52 \pm 0.01$ & $4.43 \pm 0.10$ & $4.46 \pm 0.09$ & $4.50 \pm 0.03 \mathrm{~b}$ \\
\hline 0 & $4.60 \pm 0.03$ & $4.55 \pm 0.00$ & $4.47 \pm 0.13$ & $4.55 \pm 0.06$ & $4.54 \pm 0.03 \mathrm{~b}$ \\
\hline
\end{tabular}

Ortalama/

$4.67 \pm 0.03 \mathrm{~A}$

$4.54 \pm 0.04$ в

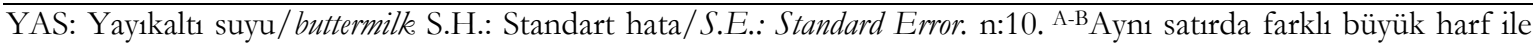
gösterilen değerler arasındaki farklar önemlidir $(\mathrm{P} \leq 0.05)$.

${ }_{\mathrm{A}-\mathrm{B}}$ Differences between the averages shown in different capital letters in the same row are significant $(P \leq 0.05)$.

a-bAynı sütunda farklı küçük harf ile gösterilen değerler arasındaki farklar önemlidir $(\mathrm{P} \leq 0.05)$.

a-bDifferences between the means shown in different lower case letters in the same column are significant $(P \leq 0.05)$.

Çizelge 4. Yayıkaltı içeceklerinin depolama süresince titrasyon asitlikleri (\% laktik asit, Ortalama \pm S.H.) Table 4. Titratable acidities (lactic acid \%, Mean \pm S.E) of buttermilk beverages during storage

\begin{tabular}{|c|c|c|c|c|c|}
\hline \multirow{3}{*}{$\begin{array}{l}\text { YAS Oran1/ } \\
\text { Rate of YAS (\%) }\end{array}$} & \multicolumn{2}{|c|}{ 1. Gün/ Day 1} & \multicolumn{2}{|c|}{ 15. Gün/Day 15} & \multirow{3}{*}{ Ortalama Mean } \\
\hline & \multicolumn{4}{|c|}{ Kültür Çeşidi/ Type of Culture } & \\
\hline & $\mathrm{ABT}$ & LA & $\mathrm{ABT}$ & LA & \\
\hline 100 & $0.47 \pm 0.11$ & $0.38 \pm 0.06$ & $0.52 \pm 0.06$ & $0.77 \pm 0.06$ & $0.54 \pm 0.11$ \\
\hline 75 & $0.50 \pm 0.12$ & $0.44 \pm 0.10$ & $0.62 \pm 0.11$ & $0.81 \pm 0.01$ & $0.60 \pm 0.12$ \\
\hline 50 & $0.56 \pm 0.15$ & $0.52 \pm 0.13$ & $0.70 \pm 0.15$ & $0.80 \pm 0.01$ & $0.64 \pm 0.10$ \\
\hline 25 & $0.49 \pm 0.12$ & $0.52 \pm 0.14$ & $0.72 \pm 0.16$ & $0.68 \pm 0.00$ & $0.60 \pm 0.09$ \\
\hline 0 & $0.47 \pm 0.12$ & $0.51 \pm 0.13$ & $0.70 \pm 0.16$ & $0.56 \pm 0.10$ & $0.56 \pm 0.07$ \\
\hline Ortalama/Mean & \multicolumn{2}{|c|}{$0.49 \pm 0.03^{a}$} & \multicolumn{2}{|c|}{$0.69 \pm 0.03^{b}$} & \\
\hline
\end{tabular}

YAS: Yayıkalt1 suyu/buttermilk S.H.: Standart hata/S.E.: Standard Error. n:10.

a-bAynı satırda farklı küçük harf ile gösterilen değerler arasındaki farklar önemlidir $(\mathrm{P} \leq 0.05)$.

${ }^{a-b}$ Differences between the averages shown in different lower case letters in the same row are significant $(P \leq 0.05)$. 
Yayıkaltı içeceklerinin viskozite değeri üzerine örnek oran1, kültür çeşidi ve depolama gününün ortak etkisi önemli bulunmuştur ( $\mathrm{P} \leq 0.05)$. ABT kültürü ile fermente edilmiş örneklerin viskozite değerlerinde \% 100 örnek oranından \% 0 örnek oranına doğru artış görülürken; örneklerin LA kültürü ile fermente edilenlerinde ise viskozite değişiminin \% 75 örnek oranı (ortalama \pm standart hata şeklinde Y75-LA için 1. gün 2.35 $\pm 0.14 \mathrm{cP}$, 15. gün $3.68 \pm 0.19 \mathrm{cP}$ ) hariç $\mathrm{ABT}$ kültürü ile fermente edilmiş örneklere benzer olduğu görülmüştür. Yayıkaltı içeceklerin viskozite değerleri (cP) 1. depolama gününde Y100ABT:2.55 \pm 0.05 , Y0-ABT: $26.77 \pm 0.73$, Y100-LA: 2.35 \pm 0.16 , Y0-LA: $27.43 \pm 1.22$; son depolama gününde Y100-ABT: $3.45 \pm 0.48$, Y0-ABT:

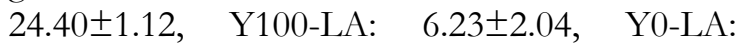
$17.83 \pm 1.51$ olarak belirlenmiştir.

Örneklerin viskozite değerleri YAS oranına göre oldukça değişkenlik göstermiştir. Ürünün bileşimi (kurumadde, protein, yağ), ürüne uygulanan 1sil işlem, üretimde kullanılan starter kültürün aktivitesi gibi faktörler viskoziteyi etkilemektedir (Hayatoğlu, 2021; Saçkesen ve Ocak, 2019; Tamuçay-Özünlü ve Koçak, 2010). Buna göre yayıkaltı ürünlerinin viskozitesini etkileyen faktörler yayıkaltının çeşidi, yayıkaltına uygulanan filtrasyon şekli, protein (kazein) miktar1, yayıkaltının asitlik ve $\mathrm{pH}$ değeri olarak düşünülmüştür. Ayrıca örneklerin viskozite değerinin yükselmesi bileşimdeki süt oranının artmas1 ve fermantasyon sürecinin etkisiyle gerçekleşmiştir. Yayıkaltı içeceklerinde (süt kontrol örnekleri ve Y25-LA hariç) son depolama gününde genel olarak viskozitenin arttığ1 gözlemlenmiştir. Benzer şekilde probiyotik ayran üzerine yapılan farklı çalışmalarda da depolama süresince ürünlerin viskozite değerlerinde artış olduğu bildirilmiştir (Kuş, 2010; Burucu, 2008; Tonguç 2006; Hayatoğlu, 2021).

Örneklerin uçucu bileşen analizleri üretimin 1 . gününde yapılmış olup toplamda 17 adet uçucu bileşen tespit edilmiştir (Çizelge 5). Uçucu bileşenlerden aseton, 2,3-butandion, asetoin, toluen, 2-heptanon, limonen ve ökaliptol tüm örneklerde belirlenmiştir. Dekan bileşiği sadece \% 100 örnek oranlarında, 1,2-Bis (trimetilsilyl) benzen bileşiği ise sadece $\% 0$ örnek oranında tespit edilmiştir. Asetoin, \% 75, \% 50, \% 25 ve $\%$ 0 örnek oranlarında miktarca en yüksek bulunan uçucu bileşen olarak belirlenmiştir.

Çalışmada tespit edilen asetoin, 2-heptanon, 2,3butandion bileşiklerinin farklı çalışmalarda da süt ürünlerinde tereyağ1 ve kremams1 lezzet kaynağ1 olarak sitrat metabolizması sonucu oluştuğu vurgulanmıştır (Alemayehu vd., 2014; Pan vd., 2014; Dan vd., 2017). Ayrica tereyağ1 aromas1 olarak bilinen diasetil (2,3-bütandion) bileşiği laktik asit bakterilerinin sitrat metabolizmas dışında laktoz metabolizması sonucu olarak da tespit edilmektedir (Kesenkaş ve Bulut, 2006; Köse ve Ocak, 2014). Söz konusu metabolizmalarda oluşan piruvat oranı yükseldikçe diasetil ve asetoin bileşiklerinin oluşumu aynı oranda artmaktadır. Diasetil, tereyağı üretimi sırasında suda çözünerek yaklaşık $3.5-7 \mathrm{mg} / \mathrm{kg}$ oraninda yayikaltı suyuna geçmektedir (Yetişemeyen ve Arı̈̈z,1995) ve asetoin geri dönüşümsüz diasetil redüktaz reaksiyonu sonucu oluşmaktadır (Keenan, 1968). Bu duruma bağlı olarak çalışmada tüm örneklerde belirlenen asetoinin miktarca diasetilden yüksek bulunmasının nedeni asetoinin diasetilden türemiş olmasındandır. Ayrıca yayıkaltı içeceklerinde süt oranının artması ile diasetil miktarının genel olarak arttığ1 ve ABT kültürü ile fermente edilen örneklerde miktarca daha fazla olduğu görülmüsstür. Benzer şekilde Nalbant ve Karagül Yüceer (2020) de diasetil miktarını en yüksek ABT kültürü ile fermente ettikleri inek sütü örneğinde bulmuşlardır.

Yayıkaltı içeceklerinin $\% 75$ ve $\% 50$ örnek oranlarında belirlenen butanal,3-metil, enzimlerin aktivitesi ile izolösin ve lösinden türemiş dallanmış yapıda bir aldehit olup (Valero vd., 2001), Dan vd., (2017) tarafindan yapilan çalışmada $L$. delbrueckii subsp. bulgaricus ve $S$. thermophilus farklı kombinasyonlarda kullanılarak süt fermente edilmiş ve ürünlerde her kombinasyonda butanal,3-metil yüksek konsantrasyonlarda tespit edilmiştir. 
Yayıkaltı örneklerinde yapılan uçucu bileşen analizinde asetik asit, butanoik asit, butanoik asit, 3-metil, hekzanoik asit, sorbik asit, benzoik asit ve oktanoik asit belirlenen asidik bileşenlerdir (Çizelge 6). \% 0 örnek oranlarında ve Y25-LA ile fermente edilmiş yayıkaltı örneği dışında tüm örneklerde bulunan sorbik asidin, yayıkaltının hammaddesi olan tereyağından geldiği düşünülmektedir.

Çizelge 5. Yayıkaltı içeceklerinin uçucu bileşenleri $(\mu \mathrm{g} / \mathrm{kg}$, Ortalama \pm S.S.)

Table 5 . Volatile compounds of buttermilk beverages $(\mu \mathrm{g} / \mathrm{kg}$, Mean $\pm S . D$

\begin{tabular}{|c|c|c|c|c|c|c|c|c|c|c|}
\hline \multirow{2}{*}{$\begin{array}{l}\text { Uçucu Bileşen } \\
\text { Volatile Compunds }\end{array}$} & \multicolumn{10}{|c|}{ Probiyotik İçecekler/Probiotic Beverages } \\
\hline & Y100-ABT & Y75-ABT & Y50-ABT & Y25-ABT & Y0-ABT & Y100-LA & Y75-LA & Y50-LA & Y25-LA & Y0-LA \\
\hline Aseton & $7.1 \pm 1.7$ & $13.0 \pm 3.2$ & $18.2 \pm 8.1$ & $27.6 \pm 3.7$ & $27.2 \pm 15.6$ & $9.8 \pm 6.6$ & $13.3 \pm 8.0$ & $11.8 \pm 4.3$ & $27.5 \pm 0.8$ & $55.3 \pm 10.5$ \\
\hline $\begin{array}{l}\text { 2,3-Butandion } \\
\text { (Diasetil) }\end{array}$ & $36.6 \pm 2.6$ & $71.2 \pm 3.9$ & $80.8 \pm 51.2$ & $116.0 \pm 8.2$ & $74.8 \pm 43.6$ & $44.4 \pm 39.6$ & $29.1 \pm 20.2$ & $28.1 \pm 11.9$ & $37.7 \pm 1.1$ & $54.0 \pm 7.8$ \\
\hline Asetoin & $120.9 \pm 3.2$ & $359.7 \pm 76.9$ & $263.4 \pm 225.2$ & $546.9 \pm 2.0$ & $523.3 \pm 295.1$ & $53.4 \pm 18.5$ & $109.8 \pm 55.9$ & $121.9 \pm 110.8$ & $492.4 \pm 69.6$ & $949.5 \pm 34.4$ \\
\hline Butanal, 3-metil & - & $11.0 \pm 0.2$ & $9.2 \pm 3.2$ & - & - & - & $68.1 \pm 46.9$ & $9.9 \pm 1.4$ & - & - \\
\hline 2,3-Pentandion & - & $33.1 \pm 0.1$ & $190.5 \pm 19.2$ & $200.6 \pm 20.2$ & $83.3 \pm 32.0$ & - & $22.8 \pm 20.9$ & $11.6 \pm 3.0$ & $64.1 \pm 16.4$ & $59.8 \pm 19.9$ \\
\hline 2-Penten, (E)- & $81.9 \pm 8.3$ & - & $44.8 \pm 28.8$ & - & - & $293.4 \pm 240.3$ & - & $34.7 \pm 10.0$ & - & - \\
\hline 1-Butanol, 3-metil- & - & $82.5 \pm 9.2$ & - & - & - & - & $6.8 \pm 6.8$ & - & - & - \\
\hline İzoamilalkol & $27.4 \pm 10.3$ & $24.7 \pm 7.5$ & $10.8 \pm 10.8$ & $13.8 \pm 0.2$ & - & $46.5 \pm 18.4$ & $71.9 \pm 43.8$ & $6.2 \pm 6.2$ & $28.5 \pm 11.5$ & - \\
\hline Toluen & $25.3 \pm 21.9$ & $61.2 \pm 40.8$ & $33.1 \pm 19.8$ & $56.0 \pm 35.6$ & $30.6 \pm 22.2$ & $19.1 \pm 5.6$ & $24.9 \pm 9.2$ & $17.1 \pm 11.0$ & $51.9 \pm 40.9$ & $51.1 \pm 29.0$ \\
\hline Hekzanal & - & - & - & $104.8 \pm 13.2$ & $57.8 \pm 11.3$ & - & - & - & $71.3 \pm 1.5$ & $66.4 \pm 3.6$ \\
\hline 1-Hekzanol & $69.3 \pm 21.6$ & $76.5 \pm 28.4$ & $68.6 \pm 55.6$ & $39.8 \pm 23.3$ & - & $180.1 \pm 149.9$ & $69.2 \pm 51.4$ & $76.4 \pm 28.1$ & $16.4 \pm 5.2$ & - \\
\hline 2-Heptanon & $27.8 \pm 4.7$ & $40.7 \pm 3.3$ & $24.4 \pm 18.9$ & $42.6 \pm 17.4$ & $30.9 \pm 14.6$ & $56.7 \pm 30.3$ & $25.8 \pm 3.2$ & $16.6 \pm 5.8$ & $28.0 \pm 9.0$ & $62.8 \pm 5.6$ \\
\hline Benzaldehit & $210.1 \pm 185.0$ & $65.8 \pm 15.9$ & $54.1 \pm 24.8$ & $7.5 \pm 1.5$ & - & $200.1 \pm 184.3$ & $94.0 \pm 18.3$ & $101.3 \pm 1.9$ & $63.0 \pm 5.6$ & - \\
\hline Dekan & $22.3 \pm 5.1$ & - & - & - & - & $5.7 \pm 5.7$ & - & - & - & - \\
\hline Limonen & $7.4 \pm 5.3$ & $8.5 \pm 1.3$ & $15.9 \pm 9.9$ & $11.8 \pm 0.4$ & $10.1 \pm 5.1$ & $11.7 \pm 2.8$ & $4.1 \pm 1.6$ & $5.3 \pm 2.3$ & $4.2 \pm 2.5$ & $5.4 \pm 0.1$ \\
\hline Ökaliptol & $10.5 \pm 8.0$ & $58.6 \pm 44.4$ & $51.4 \pm 43.4$ & $125.0 \pm 1.1$ & $120.8 \pm 31.4$ & $61.8 \pm 43.5$ & $49.4 \pm 21.7$ & $63.2 \pm 18.2$ & $36.2 \pm 0.6$ & $84.2 \pm 16.1$ \\
\hline $\begin{array}{l}1,2 \text {-Bis(trimetilsilil) } \\
\text { benzen }\end{array}$ & - & - & - & - & $61.0 \pm 53.7$ & - & - & - & - & $101.3 \pm 30.5$ \\
\hline
\end{tabular}

‘-' belirlenemedi/ Not detected. n:10. S.S. Standard sapma/S.D. Standard deviation

Benzer şekilde Türk G1da Kodeksi Katk1 Maddeleri Yönetmeliği’nde (Anonymous, 2017) katkı maddesi olarak tereyağında ve yayıkaltında kullanılmasına izin verilmediği halde fermente edilen ürünlerde bulunabilmesinde sakinca görülmeyen benzoik asit de bazı örneklerde tespit edilmiştir. Mroueh vd. (2008) de yaptıkları çalışmada yoğurt benzeri fermente süt ürünlerinde starter olarak kullanılan laktik asit bakterilerinin benzoik asiti, hippurik asidin doğal olarak enzimatik reaksiyonundan, fenilalanin degradasyonundan veya benzaldehitin otooksidasyonundan

üretebildiğini bildirmişlerdir. Çalışmada belirlenen bileșiklere benzer olarak, yayıkaltı suyu ilave edilen Cheddar tipi peynirlerde de nonanal, butanoik, hekzanoik ve oktanoik asitler belirlenmiştir (Hickey vd., 2018). Özellikle laktik asit bakteri metabolizmas1 ile de oluştuğu bildirilen diasetil, asetik asit, laktik asit ve bütanoik asitin aroma ve tat oluşumu açısından öne çıtı̆̆ı bilinmektedir (Mallia, 2008; Ergöz, 2017). 
Yayıkaltı içeceklerinin duyusal özelliklerinden tatl, tuzlu, ekşi, buruk, umami, metalik ve acı tat depolama boyunca değerlendirilmiştir. Depolama süresince azalan tatlı tat sadece süt içeren $\% 0$ örnek oranlarında daha yoğun algılanmıştır. Yayıkaltı içeceklerinde tuzlu tat beklendiği gibi YAS oranı yüksek olan örneklerde daha fazla hissedilmiştir. Tuzlu tat peyniraltı suyu ve yayıkaltı suyu gibi süt yan ürünlerinin kullanımını sinırlayan bir faktördür. Yaylkaltı suyuna göre miktarca ve kullanım alanı daha fazla olan peyniraltı suyu bu nedenle toz forma dönüştürülürken bileşiminde bazı değişiklikler yapılarak (mineralleri azaltılmış peyniraltı suyu tozu, laktozu alınmış peyniraltı suyu tozu, laktozu ve mineralleri azaltılmış peyniraltı suyu tozu, deproteinize peyniraltı suyu tozu ve yağca zenginleştirilmiş peyniraltı suyu tozu vb.) kullanılmaktadır (Özen ve Kılıç, 2007; Küçüköner, 2011). Ayrıca yapılan birçok çalışmada süt yan ürünlerinin, tadı olumsuz etkilemesi nedeniyle düşük oranlarda, süt ile farklı kombinasyonlarda veya meyvelerle aromalandırılarak tüketimi de önerilmiştir (Liutkevičius vd., 2016; Kumar vd., 2017; Chavan vd., 2015; Akan ve Kınık, 2016; Argan vd., 2015; Pescuma vd., 2010; Ersoy ve Uysal, 2002; Shaikh ve Rathi, 2009; Arora vd., 2015; Meshram, 2015).

Çizelge 6. Yayıkaltı içeceklerinde belirlenen asidik bileşikler (\%)

Table 6. Acidic compounds of buttermilk beverages (\%)

\begin{tabular}{lccccccc}
\hline \multirow{2}{*}{$\begin{array}{l}\text { Örnekler/ } \\
\text { Samples }\end{array}$} & $\begin{array}{c}\text { Asetik/ } \\
\text { Acetic }\end{array}$ & $\begin{array}{c}\text { Butanoik/ } \\
\text { Butanoic }\end{array}$ & $\begin{array}{c}\text { Butanoik, 3-metil/ } \\
\text { Butanoic, 3-metbyl }\end{array}$ & $\begin{array}{c}\text { Hekzanoik/ } \\
\text { Hexanoic }\end{array}$ & $\begin{array}{c}\text { Sorbik/ } \\
\text { Sorbic }\end{array}$ & $\begin{array}{c}\text { Benzoik/ } \\
\text { Benzoic }\end{array}$ & $\begin{array}{c}\text { Oktanoik/ } \\
\text { Octanoic }\end{array}$ \\
\hline Y100-ABT & 21.62 & 3.97 & 1.58 & 2.87 & 4.91 & - & 0.94 \\
Y75-ABT & 24.47 & 4.21 & - & 2.20 & 4.63 & 0.08 & 1.04 \\
Y50-ABT & 18.64 & 2.64 & - & 3.92 & 2.80 & 0.17 & 0.72 \\
Y25-ABT & 25.18 & 1.65 & - & 2.37 & 0.95 & 0.54 & - \\
Y0-ABT & 2.44 & 0.44 & - & 1.22 & - & - & - \\
Y100-LA & 10.15 & 1.97 & 2.07 & 1.24 & 3.13 & 0.42 & - \\
Y75-LA & 14.94 & 3.73 & - & - & 6.48 & - & 0.94 \\
Y50-LA & 15.58 & 2.60 & - & 3.17 & 4.89 & 0.05 & 0.75 \\
Y25-LA & 14.82 & 2.26 & - & 1.95 & - & 0.39 & - \\
Y0-LA & 13.87 & 1.49 & - & 2.42 & - & - & - \\
\hline
\end{tabular}

'-' belirlenemedi/ Not detected. n:10.

Yayıkaltı örneklerinde belirlenen temel tatlardan ekşi tat Y100-ABT' de 15. günde, umami tat Y100-ABT' de 1. günde, buruk tat Y100-ABT' de 1. günde, metalik tat $Y 75-A B T^{\prime}$ de 1. günde, ac1 tat ise Y100-LA' da 15. günde en yüksek değerlerde belirlenmiştir. Devam eden biyokimyasal olayların etkisiyle ekşi tat, $\mathrm{pH}$ değerinde azalma ve \% toplam asitlik artışı ile uyumlu şekilde duyusal tadımlarda da depolamanın son günü daha yoğun hissedilmiştir. Ayrıca ekşi tat üzerine kültür çeşidi ve depolama günü etkisi önemli bulunmuş olup $(\mathrm{P} \leq 0.05)$, depolamanın 15. gününde $\mathrm{ABT}$ kültürü ile fermente edilmiş ürünlerin ekşi algısı (2.98 \pm 0.19$)$,
LA kültürü ile fermente edilenlere göre $(2.17 \pm 0.17)$ daha fazla bulunmuştur.

Yayıkaltı içeceklerinde depolama süresince pişmiş, kremams1, süthane/sütümsü, fermente, karton, yosun, sabunsu ve depo belirlenen duyusal terimler olmuştur. Kremamsı lezzet sadece süt içeren $\% 0$ YAS kodlu örneklerde ilk günde en baskın duyusal özellik olarak değerlendirilmiştir. Yayıkaltı örneklerinde hissedilen sabunsu tada, süt ürünlerinde ester bileşiklerinin konsantrasyonuna bağlı olarak uzun zincirli yağ asidi etil esterleri (Akpinar vd., 2006) neden olmuştur. 
Örneklerde YAS oranlarının, tatli, tuzlu, buruk, ac1, kremams1, karton, yosun ve sabunsu terimleri üzerinde önemli etkisi olduğu bulunmuştur ( $\mathrm{P}$ $\leq 0.05$; Çizelge 7). Tatlı ve kremamsı özellikler en çok \% 0 örnek oranlarında; tuzlu, buruk, karton, yosun, sabunsu ve ac lezzetler ise \% 100 YAS oranındaki örneklerde en belirgin özellikler olarak tespit edilmiştir.
Yayıkaltı içeceklerinde belirlenen tatlı, umami, metalik, pişmiş, kremamsı, yosun, acı ve depo terimleri üzerine depolama günün etkisi önemli bulunmuştur ( $\mathrm{P} \leq 0.05)$. Buna göre tatl

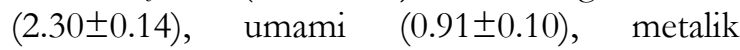
(0.88 \pm 0.28$), \quad$ pişmiş $(2.45 \pm 0.21)$, kremams1 $(2.59 \pm 0.11)$ ve yosun $(0.84 \pm 0.19)$ terimleri depolamanın ilk günü; acı $(0.34 \pm 0.08)$ ve depo $(0.28 \pm 0.09)$ terimleri ise depolamanın son günü daha yoğun hissedilmiştir.

Çizelge 7. İçeceklerde duyusal terimler üzerine YAS oranı etkisi (Ortalama \pm S.H.) Table 7. The effect of YAS rate on some sensory descriptors in beverages (Mean $\pm S$.E.)

\begin{tabular}{|l|c|c|c|c|c|}
\hline \multirow{2}{*}{$\begin{array}{l}\text { Tanimlayic1 terimler/ } \\
\text { Descriptive terms }\end{array}$} & \multicolumn{5}{|c|}{ YAS Oran1 (\%)/Rate of YAS (\%) } \\
\cline { 2 - 6 } & 100 & 75 & 50 & 25 & 0 \\
\hline Kremams1/Creamy & $2.22 \pm 0.17^{\mathrm{b}}$ & $2.25 \pm 0.10^{\mathrm{b}}$ & $2.33 \pm 0.14 \mathrm{ab}$ & $2.49 \pm 0.16^{\mathrm{ab}}$ & $2.94 \pm 0.13^{\mathrm{a}}$ \\
\hline Karton/Cardboard & $0.80 \pm 0.06^{\mathrm{a}}$ & $0.41 \pm 0.09^{\mathrm{b}}$ & $0.14 \pm 0.05^{\mathrm{bc}}$ & $0.06 \pm 0.03^{\mathrm{c}}$ & $0.08 \pm 0.05^{\mathrm{c}}$ \\
\hline Yosun/Algae & $2.19 \pm 0.19^{\mathrm{a}}$ & $1.70 \pm 0.28^{\mathrm{ab}}$ & $0.86 \pm 0.26 \mathrm{bc}$ & $0.29 \pm 0.16^{\mathrm{c}}$ & $0.26 \pm 0.17 \mathrm{c}$ \\
\hline Sabunsu/Soap & $1.85 \pm 0.67^{\mathrm{a}}$ & $0.79 \pm 0.16^{\mathrm{ab}}$ & $0.50 \pm 0.17 \mathrm{~b}$ & $0.60 \pm 0.28^{\mathrm{b}}$ & $0.12 \pm 0.10^{\mathrm{b}}$ \\
\hline Tatli/Sweet & $1.51 \pm 0.16^{\mathrm{b}}$ & $1.87 \pm 0.21^{\mathrm{ab}}$ & $2.06 \pm 0.26^{\mathrm{ab}}$ & $2.11 \pm 0.21 \mathrm{ab}$ & $2.50 \pm 0.16^{\mathrm{a}}$ \\
\hline Tuzlu/Salty & $2.06 \pm 0.16^{\mathrm{a}}$ & $2.01 \pm 0.18^{\mathrm{ab}}$ & $1.68 \pm 0.16^{\mathrm{abc}}$ & $1.41 \pm 0.12 \mathrm{bc}$ & $1.12 \pm 0.10^{\mathrm{c}}$ \\
\hline Buruk/Sour & $2.41 \pm 0.19^{\mathrm{a}}$ & $2.36 \pm 0.09^{\mathrm{a}}$ & $2.08 \pm 0.11 \mathrm{ab}$ & $1.90 \pm 0.17 \mathrm{ab}$ & $1.63 \pm 0.13^{\mathrm{b}}$ \\
\hline Ac1/Bitter & $0.60 \pm 0.14^{\mathrm{a}}$ & $0.26 \pm 0.14^{\mathrm{ab}}$ & $0.08 \pm 0.05^{\mathrm{b}}$ & $0.02 \pm 0.02^{\mathrm{b}}$ & $0.05 \pm 0.05^{\mathrm{b}}$ \\
\hline
\end{tabular}

YAS: Yay1kaltı suyu/buttermilk S.H.: Standart Hata/ S.E.: Standard Error n: 10.

a-c Aynı satırda farklı küçük harf ile gösterilen değerler arasındaki farklılıklar önemlidir $(\mathrm{P} \leq 0.05)$.

${ }^{a-c}$ Differences between the averages shown in different lower case letters in the same row are significant $(P \leq 0.05)$.

YAS oranı yüksek örneklerde karton tadının fazla hissedilmesi benzer şekilde Sodini vd. (2006) tarafindan da bildirilmiştir. Araştırmacılar tarafindan karton tadının toz formda kullanilan yayikaltı suyu ve yayikaltı suyunun konsantrasyonunun artışıla birlikte daha yoğun hissedildiği bildirilmiştir. Ayrıca karton lezzeti doymamış serbest yağ asitlerinin oksidasyonu (Carunchia-Whetstine vd., 2003) sonucunda da oluşabilmektedir. Hickey vd. (2018) tarafindan yayıkaltı ilave edilen Cheddar tipi peynirlerde ac1 tat, okside lezzet ve istenmeyen aromalarnn daha fazla algılandığ 1 belirtilmiştir.

Depolama süresince gerçekleştirilen tanımlayıcı duyusal analizler sirasinda panelistler \% 50 oranında hazırlanan yayıkaltı suyu içeceklerini daha çok beğenirken özellikle ABT kültürü ile fermente edilmiş \% 50 oranında YAS içeren içeceği ilk sırada tercih ettiklerini sözlü olarak ifade etmişlerdir.
Sonuç olarak, yayıkaltı suyunun farklı oranlarda süt ile formüle edilmesi ve farklı kültürlerle fermantasyonu bu içeceklerin birbirlerinden farklı özellikler kazanmasına sebep olmuştur. Yayıkaltı içeceklerinin viskozitesi oldukça değişken olup genel olarak son depolama gününe doğru artış göstermiştir. Yayıkaltının süt ile formüle edilmesi inoküle edilen kültürler için besiyeri ortamı oluşturarak fermantasyon süresini kısaltmıştır. Tüm yayıkaltı içeceklerinde belirlenen diasetil ve asetoin bileşikleri ABT kültürü ile fermente edilmiş örneklerde LA kültürü ile fermente edilmiş örneklere göre daha fazla tespit edilmiştir. Duyusal olarak yayıkaltı suyu oranının yüksek olduğu içeceklerde tuzlu tat daha fazla hissedilmiş olup sadece yayıkaltı suyu bileşimine sahip ürünlerde tuzlu tadın yanı sıra buruk, karton, yosun, sabunsu ve ac1 lezzetler belirgin hissedilmiştir. Yayıkaltı suyu bileşimindeki yüksek protein oranına bağlı olarak depolamanın son gününde acı tat gelişmiştir. Ayrıca çalşsmada yayıkaltı suyunun toz formdan elde edilmesine 
bağlı olarak da karton terimi YAS oranı yüksek içeceklerde fazla hissedilmiştir. Bu sonuçlara bakıldığında \% 50 oranlarına kadar kullanılması durumunda yayıkaltı suyu ile elde edilen içeceğin kabul edilebilir bir tatta olacağı düşünülmektedir. Çalışma sonucunda elde edilen bilgiler yayıkaltı suyu da dahil olmak üzere süt yan ürünlerinin alternatif içecek olarak değerlendirilmesinin mümkün olduğunu göstermektedir. Yayıkaltının tek başına kullanılması yerine süt ile kombinasyonlarının geliştirilmesi, farklı kültürler ile fermantasyonu ve farklı meyve veya sebze suları ile aromalandırılması süt yan ürünlerinin geri kazanımı ve tüketimi açısından daha kabul edilebilir olmasını sağlayacaktır.

\section{TEŞEKKÜR}

Bu makale Çisem Öğe' nin 'Süt Yan Ürünlerinin Fermentasyonu ve Karakteristik Bazı Özellikleri' başlıklı yüksek lisans tezinin bir kısmından (Çanakkale Onsekiz Mart Üniversitesi, Lisansüstü Eğitim Enstitüsü, YÖK Tez No: 596916) düzenlenmiştir. Çalışma Çanakkale Onsekiz Mart Üniversitesi Bilimsel Araştırma Projeleri Koordinasyon Birimi kapsaminda (Proje no: FYL-2018-2479) desteklenmiştir.

\section{ÇIKAR ÇATIŞMASI BEYANI}

Yazarların, başka kişiler ve/veya kurumlar ile çıkar çatışması bulunmamaktadır.

\section{YAZAR KATKILARI}

ÇÖ, hammadde temini ve örneklerin üretimi, analizlerin uygulanmasi ve verilerin elde edilmesi, makalenin yazımı, düzenlenmesi ve görselleştirilmesine katkıda bulunmuştur. YKY, danışman olarak çalışmanın ve makalenin metodolojisi ve düzenlemesinde katkıda bulunmuştur. Katkıda bulunan tüm yazarlar makalenin son halini okuduğunu ve onayladığını kabul etmektedir.

\section{KAYNAKLAR}

Affolter, M., Grass, L., Vanrobaeys, F., Casado, B., Kussmann, M. (2010). Qualitative and quantitative profiling of the bovine milk fat globule membrane proteome. J Proteomics, 73: 1079-1088, doi: http://dx.doi.org/10.1016/ j.jprot.2009.11.008.
Akal, C., Yetişemeyen, A. (2020). Probiyotik ve prebiyotik tüketiminin laktoz intoleransı üzerine etkileri. GIDA, 45(2): 380-389, doi: 10.15237 /gida.GD20016.

Akan, E., Kınık, Ö. (2016). Sağlıklı içecek üretiminde yeni bir eğilim: siyah havuç ve kırmızı pancar ilaveli sinbiyotik peynir altı suyu içeceği üretimi. 4. Uluslararası Gida Ar-Ge Proje Pazarı, İzmir.

Akpınar, A., Uysal, H., Kınık, Ö. (2006). Süt ve süt ürünlerinde lezzet bileşeni olarak esterler ve esterlerin biyosentezi. Türkiye 9. Gida Kongresi; 24-26 Mayıs 2006, Bolu, Türkiye.

Alemayehu, D., Hannon, J.A., Mcauliffe, O., Ross, R.P. (2014). Characterization of plantderived lactococci on the basis of their volatile compounds profile when grown in milk. Int J Food Microbiol, 172: 57-61, doi: https://doi.org/10.1016/j.ijfoodmicro.2013.11.0 24.

Anonymous (2017). Türk Gida Kodeksi. Gida Katkı Maddeleri Yönetmeliği. Tarım ve Orman Bakanlığı 03.04.2017 tarih ve 30027 sayılı Resmî Gazete, Ankara.

Argan, B.E., Güneşer, O., Kırca-Toklucu, A., Karagül-Yüceer, Y. (2015). Peyniraltı suyu tozu ilave edilmiş meyveli içecek üretimi ve bazı kalite karakteristikleri. Türk Tarm-Gıda Bilim ve Teknoloji Dergisi, 3(8): 651-658.

Arora, A., Mayta-Apaza, A., Ortega-Anaya, J., Jimenez-Flores, R. (2015). Development and characterization of a children's beverage using byproducts from the dairy industry. The Ohio State University Department of Food Science and Technology, Undergraduate Research Theses, Fyffe Ct., Columbus.

Avşar, Y.K., Karagül-Yüceer, Y., Drake, M.A., Singh, T.K., Yoon, Y., Cadwallader, K.R. (2004). Characterization of nutty flavor in cheddar cheese. J Dairy Sci, 87:1999-2010, doi: 10.3168/jds.S0022-0302(04)70017-X.

Bachmann, H.P. (2001). Cheese analogues: a review. Int. Dairy J., 11: 505-515, https://doi.org/10.1016/S0958-6946(01)000735. 
Bradley, Jr.R.L., Arnold, Jr.E., Barbano, D.M., Semerad, R.G., Smith, D.E., Vines, B.K. (1992). Chemical and Physical Methods. In Standard Methods for the Examination of Dairy Products, ed: Marshall, R.T., American Public Health Association, Washington D.C., 433-531.

Burucu, H. (2008). Ayran üretiminde peynir alt1 suyu ürünleri ile kappa karreganan kullanımının duyusal fiziko-kimyasal ve probiyotik özellikler üzerine etkisi. Selçuk Üniversitesi Fen Bilimleri Enstitüsü Gıda Mühendisliği Ana Bilim Dalı Yüksek Lisans Tezi, Konya, Türkiye, 77 s.

Carunchia-Whetstine, M.E., Parker, J.D., Drake, M.A., Larick, D.K. (2003). Determining flavor and flavor variability in commercially produced liquid Cheddar whey. J. Dairy Sci. 86:439-448, doi: https://doi.org/10.3168/jds.S0022-

0302(03)73622-4.

Chavan, R.S., Nalawade, T., Anit, K. (2015). Studies on the development of whey based mango beverage. RRJFPD, 3(2): 2347-2359.

Corredig, M., Roesch, R.R., Dalgleish, D.G. (2003). Production of a novel ingredient from buttermilk. J. Dairy Sci., 86: 2744-2750, doi: https://doi.org/10.3168/jds.S0022-

0302(03)73870-3.

Cumhur, Ö. (2008). Peynir benzeri bir üründe farklı protein kaynaklarının yapısal özelliklere etkilerinin belirlenmesi. İstanbul Teknik Üniversitesi Fen Bilimleri Enstitüsü Gıda Mühendisliği Anabilim Dalı Yüksek Lisans Tezi, İstanbul, Türkiye, $62 \mathrm{~s}$.

Dan, T., Wang, D., Wu, S., Jin, R., Ren, W., Sun, T. (2017). Profiles of volatile flavor compounds in milk fermented with different proportional combinations of Lactobacillus delbrueckii subsp. bulgaricus and Streptococcus thermophilus. Molecules, 22(10):1633, doi: 10.3390/molecules22101633.

Ergöz, E. (2017). Manda sütünden üretilen yayık ve krema tereyağlarının nitelikleri. Ankara Üniversitesi Fen Bilimleri Enstitüsü Süt Teknolojisi Anabilim Dalı Yüksek Lisans Tezi, Ankara, Türkiye, $40 \mathrm{~s}$.

Ersoy, M., Uysal, H. (2002). Süt tozu, peyniralt1 suyu ve yayıkaltı karışımları ile üretilen kefirlerin özellikleri üzerine bir araştırma/1. bazı kimyasal özellikler. Ege Üniv. Ziraat Fak. Derg, 39(3): 64-71.

Hayatoğlu, F. (2021). Probiyotik bakteri ilavesi ile üretilen ayranların fiziksel, kimyasal ve mikrobiyolojik özellikleri. Afyon Kocatepe Üniversitesi Gıda Mühendisliği Anabilim Dalı Yüksek Lisans Tezi, Afyon, Türkiye, 138 s.

Hickey, C.D., O'Sullivan, M.G., Davis, J., Scholz, D., Kilcawley, K.N., Wilkinson, M.G., Sheehan, J.J. (2018). The effect of buttermillk or buttermilk powder addition on functionality, textural, sensory and volatile characteristics of Cheddarstyle cheese. Food Res Int., 103: 468-477, doi: https://doi.org/10.1016/j.foodres.2017.09.081.

Keenan, T.W., Bills, D.D. (1968). Metabolism of volatile compounds by lactic starter culture microorganisms. J Dairy Sci., 51(10):1561-1567, doi: $\quad$ https://doi.org/10.3168/jds.S00220302(68)87231-5.

Kesenkaş, H., Akbulut, N. (2006). Destek kültür olarak kullanilan bazı mayaların beyaz peynir aromasi üzerine etkileri. Ege Üniv. Ziraat Fak. Derg, 43(2):73-84.

Köse, S., Ocak, E. (2014). Yoğurtta lezzet bileşenlerinin oluşumu ve bu oluşum üzerine etki eden faktörler. Akademik Gıda, 12(2): 101-107.

Kumar, K., Singh, J., Chandra, S., Samsher, (2017). Formulation of whey based pineapple herbal beverages and its storage conditions. Chem Sci Rev Lett, 6(21):198-203.

Kuş, H. (2010). İnsan orjinli probiyotik bakteriler kullanılarak probiyotik ayran üretimi. Namık Kemal Üniversitesi Fen Bilimleri Enstitüsü Yüksek Lisans Tezi, Tekirdağ, Türkiye, 62 s.

Küçük, H. (2013). Süt endüstrisinde atık ürünlerin değerlendirilmesi ve önemi. IV. Süt ve Süt Hayvancilı̆̆ Öğrenci Kongresi, 17 Mayıs, Karacabey-Bursa, Türkiye, 68-73 s.

Küçüköner, E. (2011). Peynir tozu ve peyniralt1 suyu tozu üretimi. 1.Ulusal Helal ve Sağllklı Gida Kongresi, 19-20 Kasım, Ankara, Türkiye, 80-85 s.

Liutkevičius, A., Speičienė, V., Alenčikienè, G., Mieželienè, A., Narkevičius, R., Kaminskas, A., Abaravičius, J.A., Vitkus, D., Jablonskienè, V., 
Sekmokiené, D. (2016). Fermented buttermilkbased beverage: impact on young volunteers' health parameters. Czech J. Food Sci., 34: 143-148, doi: 10.17221/344/2015-CJFS.

Madenci, A.B., Aktaş, K., Türker, S. (2013). Yayıkaltının sağlıklı beslenme açısından önemi ve firıncilık ürünlerinde kullanımı. Uluslararası 2. Helal ve Sağlıklı Gıda Kongresi, 7-10 Kasım, Konya, Türkiye, 656-657 s.

Mallia, S., Escher, F., Schlichtherle-Cerny, H. (2008). Aroma-active compounds of butter: a review. Eur Food Res Technol 226:315-325, doi: 10.1007/s00217-006-0555-y.

Meilgaard, M., Civille, G.V., Carr, B.T. (1999). Descriptive Analysis Techniques, Sensory Evaluation Techniques, 3. Edition CRC Press, Inc. Boca Raton, FL., 387 p.

Meshram, B.D. (2015). Butter-milk based fruit juice beverages. Asian J. Dairy \& Food Res, 34(4): 297-299, doi: 10.18805/ajdfr.v34i4.6882.

Morin, P., Jiménez-Flores, R., Pouliot, Y. (2007). Effect of processing on the composition and microstructure of buttermilk and its milk fat globule membranes. Int Dairy J, 17: 1179-1187, doi:10.1016/j.idairyj.2007.03.010.

Mroueh, M., Issa, D., Khawand, J., Haraty, B., Malek, A., Kassaify, Z., Toufeili, I. (2008). Levels of benzoic and sorbic acid preservatives in commercially produced yoghurt in Lebanon. $J$ Food Agric Environ, 6(1): 62-66.

Nalbant, D., Karagül Yüceer, Y. (2020). İnek ve keçi sütü kullanılarak üretilen probiyotik fermente süt ürünlerinin karakteristik özellikleri. GID $A 45$ (2): 315-328, doi: 10.15237/gida.GD19126.

NEN, (1969). Netherlands Standard. Butyrometric Determination of the Fat Content of Cheese (Gerber van Gulik Method). Neth Milk. and Dairy J, 23: 214-220.

NIST, (2008). NIST /EPA /NIH Mass Spectral Library (NIST 08). National Institute of Standards and Technology Standard Reference Data Program, Gaithersburg, MD20899.
Özen, A.E., Kılıç, M. (2007). Peyniraltı suyundan elde edilen serum proteinlerinin fonksiyonel özellikleri. GTED 3: 45-49.

Pan, D.D., Wu, Z., Peng, T., Zeng, X.Q., Li, H. (2014). Volatile organic compounds profile during milk fermentation by Lactobacillus pentosus and correlations between volatiles flavor and carbohydrate metabolism. J. Dairy Sci. 97:624-631, http://dx.doi.org/10.3168/jds.2013-7131.

Pescuma, M., Hebert, E.M., Mozzi, F., Fon de Valdez, G. (2010). Functional fermented wheybased beverage using lactic acid bacteria. Int J Food Microbiol, 141: 73-81, doi: 10.1016/j.ijfoodmicro.2010.04.011.

Saçkesen, S.. N. D., Ocak, E. (2019). Peyniraltı suyuyla zenginleştirilmiş fermente süt içeceği üretimi. YYÜ Tar Bil Derg, 29 (2): 309-317, doi: 10.29133/yyutbd.486896.

Shaikh, M.F.B., RathI, S.D. (2009). Utilisation of buttermilk for the preparation of carbonated fruit-flavoured beverages. Int J Dairy Technol, 62(4), doi: 10.1111/j.1471-0307.2009.00527.x.

Sodini, I., Morin, P., Olabi, A., Jime'nez-Flores, R. (2006). Compositional and functional properties of buttermilk: a comparison between sweet, sour, and whey buttermilk. J. Dairy Sci., 89: 525-536, doi: https://doi.org/10.3168/ jds.S0022-0302(06)72115-4.

Tamuçay-Özünlü, B., Koçak, C. (2010). Süte farklı ssıl işlem uygulamalarının ayran kalitesine etkisi. GID $A$, 35(5): 355-362.

Tonguç, E. (2006). Probiyotik ayran üretimi üzerine bir araştırma. Ege Üniversitesi Fen Bilimleri Enstitüsü Süt Teknolojisi Anabilim Dal, Yayımlanmamış Yüksek Lisans Tezi, İzmir, Türkiye, $153 \mathrm{~s}$.

TUIK (2020). Süt ve Süt Ürünleri Üretimi. https://data.tuik.gov.tr/Bulten/Index?p=37231 \&dil=1 (Erişim tarihi: 20.02.2021).

Valero, E., Villamiel, M., Miralles, B., Sanz, J., MartîNez-Castro, I. (2001). Changes in flavour and volatile components during storage of whole and skimmed UHT milk. Food Chem, 72(1): 51-58, doi: $\quad$ https://doi.org/10.1016/S03088146(00)00203-X. 
Wiley, (2005). Wiley Registry of Mass Spectral Data 7. Edition (Fred. W. McLafferty), 2005 (CD$\mathrm{ROM})$.

Yetişemeyen, A., Arıöz, N. (1995). Farklı koyulaştırma oranı ve kurutma sıcaklığında elde edilen yayikaltı tozunun kalite kriterlerinin belirlenmesi. GID A, 20(2): 117-122.

Yıldırım, C.., Güzeller, N. (2013). Peyniraltı suyu ve yayıkaltının toz olarak değerlendirilmesi. C.Ü.Z.F. Dergisi, 28(2): 11-20. 